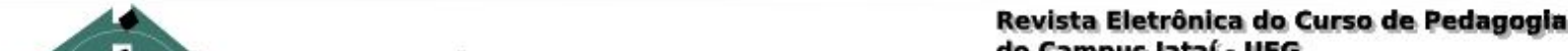 do Campus Jataí - UFG

\section{UMA NARRATIVA HISTÓRICA E DIALÓGICA NO ROMANCE MEMORIAL DO CONVENTO DE JOSÉ SARAMAGO}

\author{
Rosidelma Pereira Fraga ${ }^{1}$ \\ rosidelmapoeta@yahoo.com.br. \\ http://lattes.cnpq.br/5017383387520947
}

RESUMO: Este artigo tem como objetivo fulcral refletir sobre a problemática do tempo, do foco narrativo e do discurso no romance contemporâneo, Memorial do convento, do Nobel José Saramago. O artigo toma como fundamentação as teorias relevantes ao objeto da narrativa, a partir de Gérard Genette (s.d), Jean Pouillon (1974), Paul Ricouer (1994), Mikhail Bakhtin (1988), Walter Benjamim (1983), Maurice Blanchot (1987), dentre outros pressupostos que permitem discutir sobre o tempo, narrador e o discurso, adotando um método dialógico, a partir de uma interface com a História e a Ficção.

Palavras-chave: José Saramago; tempo, foco narrativo; discurso dialógico.

\section{Considerações preliminares}

A leitura da obra Memorial do convento de José Saramago, dentre outros elementos essenciais da narrativa, permite um estudo acerca do tempo rememorado. O romance centra-se no processo de articulação do tempo no curso das ações dos personagens históricos e ficcionais, permitindo reflexões acerca da problemática do tempo na narrativa, do foco narrativo e do discurso.

Considere-se, como princípio discursivo, que o tempo e o narrador são elementos cruciais no ato de narrar, valendo-se sempre de um ou mais discursos. Evidentemente, não há narrativa ou música que não se aproprie do tempo, assim como não existe poesia sem ritmo. A crença mais antiga das narrativas, segundo Walter Benjamin (1983), remete-nos ao fato de que todo ato de contar histórias utilizar-se-á do tempo, ainda que não se narre a temporalidade. Conforme Paul Ricouer (1978, p.16), ao contar suas histórias, “os homens articulam suas

\footnotetext{
${ }^{1}$ Prof ${ }^{a}$ Msc em Estudos Literários, pela Universidade Federal de Goiás.
} 


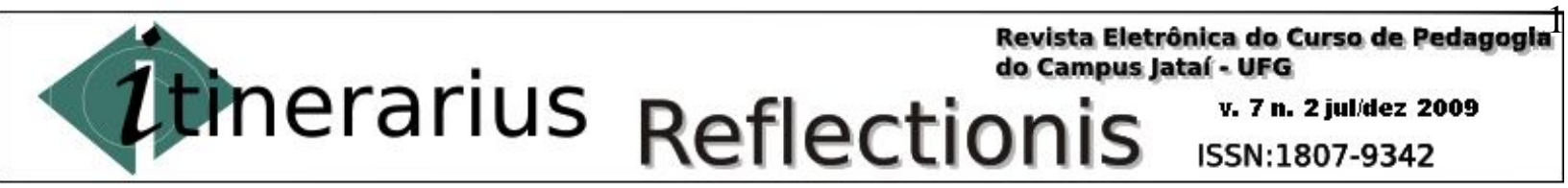

experiências do tempo". Em virtude do tempo na arte de narrar, Benedito Nunes (1988) mostra que haverá sempre um paradoxo na narração porque toda narrativa precisará de um ou vários tempos, uma vez que o tempo na narrativa pode ser apresentado de forma implícita.

Em Memorial do convento, a narrativa trata-se de uma reconstrução ou (des) construção de um fato histórico no tempo presente. Esse momento atual é utilizado por meio do processo de anamnesis (uma recordação do passado, embora recriado na ficção).

\section{Narração histórica, tempo e discurso}

O romance ocupa-se das figuras do rei e da rainha, do clero e do povo. O leitor tem a impressão de estar diante de uma narrativa histórica, de perfil pitoresco e satírico, mormente, no que se refere ao enfoque irreverente que dá às figuras da rainha e do rei no primeiro capítulo, dosando de forma equilibrada a relação entre História e Ficção. Esta relação no âmbito da desconstrução no romance do Nobel José Saramago foi analisada a fundo pelo pesquisador Odil Oliveira Filho (1993) como uma proposta do discurso de carnavalização na obra Carnaval no convento: intertextualidade e paródia em José Saramago.

Pode-se afirmar que, até o terceiro capítulo, o leitor ainda percebe a oscilação entre História e Ficção ao passo que, a partir do segundo capítulo, presencia o tom pictórico sobre a vida do clero português no século XVIII, embora também exista um tom ficcional. O terceiro capítulo dará ênfase nos costumes do povo português dessa mesma época. Entretanto, a partir do quarto capítulo, o narrador desvencilha-se do caráter histórico e dá lugar à ficção, pois ao introduzir o personagem Baltazar como responsável pela ficção, o primeiro narrador desvela-se o tom irônico como indícios de uma linguagem plural e não somente mimética. É a partir de Baltazar que a história passa a ser narrada, com outra perspectiva desse capítulo ao fim da narrativa.

A rigor, a obra de Saramago possibilita uma reinterpretação da vida de D.João V, no século XVIII, a fim de recuperar o que já foi vivido com o objetivo de compreender o momento presente. Nessa perspectiva, Memorial do convento propõe uma leitura da reinvenção da memória da coletividade (nação) para que o presente narrado tenha sentido.

Destarte, pode-se explicar que a narrativa contém elementos suficientes para que o leitor perceba, através de sua consciência intertextual, uma nova leitura de Portugal em pleno século 
$\mathrm{XX}$, bem como da figura de D. João V. Saramago dá outra roupagem na construção do gigantesco e mirabolante convento de Mafra. A historiografia portuguesa atribuiu a D.João V o grande mérito da construção do convento como se ele fosse individualmente capaz de criá-lo. Na ficção, a espinha dorsal é "remontar" a personalidade histórica e, aos poucos, com base em algumas estratégias no ato de narrar, dar maior destaque aos personagens negados nos documentos históricos do passado.

A propósito, salienta-se a opinião do escritor do Memorial do convento sobre o fato histórico e a intenção de criar a sua narrativa ficcional:

A construção do convento de Mafra foi uma demonstração, entre outros, da megalomania de D.João V, graças à exploração do ouro e dos diamantes do Brasil. Ali foi enterrada uma fortuna incalculável. Mas é impossível apurar quanto, porque todos os documentos foram destruídos. Pois bem, sendo eu um homem de esquerda, com um pensamento marxista, não poderia deixar de me impressionar com o fato de 40 mil homens terem construído aquela obra... (SARAMAGO, apud ADRIANA MARTINS, 1994, p.2).

Neste excerto de caráter exemplificativo, é evidente que o próprio narrador (não o autor), ao distanciar o personagem D.João V, desconstrói a sua figura histórica na ficção. Mais precisamente quando o narrador focaliza Blimunda Sete Luas e Baltazar Sete Sóis, ou no instante em que concede voz aos trabalhadores do convento de Mafra (João Tanoeiro, Zé Pequeno, Manuel Milho, João Anes, entre outros) para contar as suas próprias histórias.

É nesse contexto que o foco histórico, dentro da narrativa de Saramago, perde o sentido anterior e ganha outros significados. O que importa ao destinatário (leitor) não é mais a ação do tempo passado, embora esse passado tenha servido para a construção de um Portugal contemporâneo, no tempo presente chamado agora. Na obra, há um distanciamento do tempo passado. Sobre essa marca temporal, Benedito Nunes (1988, p.44) menciona:

Não será descabido tomar o presente, quando o texto em que aparece tem efeito distanciador, por um falso pretérito, que permite efetuar o recuo estético em forma de aproximação dramática. Veja-se o emprego desse tempo no romance de José Saramago. Memorial do convento, para narrar uma fábula do 


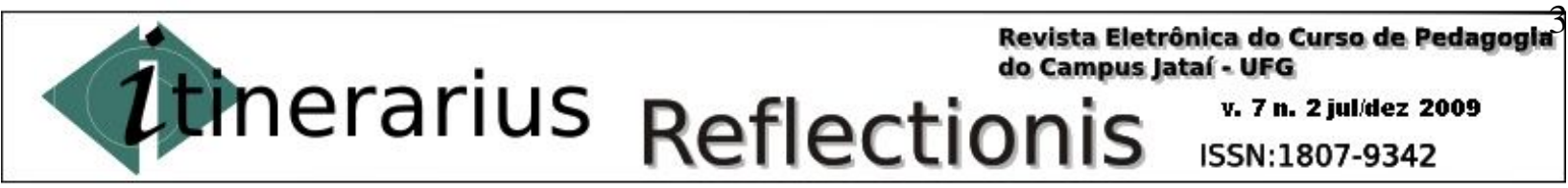

passado precisamente o período do reino de D. João V, no século XVIII, por ordem de quem se constrói o convento de Mafra. (NUNES, 1988, p. 44).

O problema do tempo em Memorial do convento insere-se no fato de o passado subsistir e insistir na forma do pretérito. A narração, em terceira pessoa, centra-se no fato passado em um momento atual. Trata-se de um passado transposto para um 'quase-passado', visto que o tempo da narrativa não decorre apenas das relações entre o narrador e o texto, mas, de certo modo, das relações entre a narrativa e o seu receptor.

O passado histórico, aos olhos do destinatário, é desconstruído não somente a respeito do convento de Mafra, mas no tocante à descrição da passarola de Padre Bartolomeu de Gusmão, no transporte da pedra de Pêro Pinheiro, a qual representa a queda do poder do rei. Observe, por exemplo, que a pedra, sem a força dos trabalhadores de Mafra, fará com que "o poder de El-rei será vento, pó e coisa nenhuma” (SARAMAGO, 1987, p. 244).

Em Memorial do convento, há o "resgate" dessa historiografia com um recurso de transformação de um fato. O narrador rompe paradoxalmente com o fato real. Essa mudança remete-nos à concepção de Aristóteles (1987) no que tange à seguinte reflexão: o objetivo da história não é narrar os fatos como realmente aconteceram, mas como o narrador gostaria que tivesse acontecido.

Nessa perspectiva, pode-se verificar a marca dialogia, sustentada na tese de Mikhail Bakhtin (1988) em Questões de literatura e estética, uma vez que as vozes infiltradas no discurso romanesco de Saramago permitem uma leitura dialógica com a História. Na verdade, "no discurso dialógico convergem duas enunciações iguais e diretamente orientadas para o objeto. Após penetrar na palavra do outro e nela se instalar". (BAKHTIN, 1988, pp. 164 - 168).

O tempo passado, em certos momentos da narrativa do romance Memorial do convento, configura uma problemática porque as ações, narrações e descrições, entre outros elementos, não remetem a uma pura caracterização do tempo. Segundo Roland Barthes (1971), o tempo pode entrar em contradição com a lógica. Esse elemento contraditório pode ser observado a partir da demarcação de 1.717 , como se lê no último capítulo, bem como no relato da morte do escritor brasileiro Antônio José da Silva em 1739. Note-se que se o leitor focalizar essas datas poderá obter uma duração de vinte e dois anos, mas há no vigésimo primeiro capítulo outras marcas temporais, a saber: 
[...] a vontade de vossa majestade é digna do grande rei que mandou edificar Mafra (...), entre a bênção da primeira pedra e a consagração, consumiu cento e vinte anos de trabalhos e riquezas, vossa majestade, que eu saiba, nunca lá esteve, julga pelo modelo de armar que aí tem, talvez nem daqui a duzentos e quarenta anos o conseguíssemos (...), o que eu pergunto, com todo respeito, se é que vale a pena construir uma basílica que só ficará terminada no ano dois mil, supondo que nessa altura ainda há mundo (SARAMAGO, 1987, p. 263).

Nesse fragmento, salienta-se que a narrativa, apesar dessa confusão, estabelece uma reação de linearidade dos fatos. A inteligência do narrador no aspecto temporal chama a atenção do leitor. Verifica-se a data da morte do comediógrafo (1739), somada aos cento e vinte anos da consagração apontada acima e acrescentada aos duzentos e quarenta anos, em que o leitor detecta o tempo cronológico na citação: "certamente a basílica estaria provavelmente pronta no ano dois mil". O leitor consegue somar uma seqüência temporal supostamente provável para falar de um temps chronique ${ }^{2}$ : a narrativa teria então uma duração temporal de vinte e dois anos, mas poderia ter ainda o tempo de duração da construção do convento, não o de Mafra, mas o convento reinventado pelo narrador, o qual equivale ao tempo de trezentos e sessenta anos para ser concluído até o ano dois mil.

Destarte, há um fato posterior que liga a um anterior nos vinte e cinco capítulos, exceto quando o narrador suspende a narrativa e começa a descrever o espaço, as ruas de Lisboa, a trajetória de Blimunda e Baltazar, bem como o relacionamento da Rainha com o Rei D.João V. Nesses instantes, há a transcendência do tempo da história, fazendo com que a seqüência da narrativa suspenda a coerência. Sobre essa suspensão Sheldon Sacks (1964) assegura que:

É meramente um truísmo (...) exigir que uma obra deva ser essencialmente coerente, se podemos reconhecer nela um episódio como uma digressão do tipo definido: coerência não é uma virtude de nenhum romance, é simplesmente uma condição de ser desse romance. Um romancista habilidoso pode explorar as qualidades de incidentes digressivos para atingir efeitos impossíveis de serem atingidos sem eles. (SACKS, 1964, p. 213).

\footnotetext{
${ }^{2}$ Termo utilizado por Benedito Nunes para explicar que o tempo cronológico desloca-se de um ponto a outro como um salto temporal (time-shift).
} 
A narrativa de Saramago também utiliza dessas digressões, suspendendo a sua linearidade. Ao descrever os passos de Blimunda nas ruas sujas de Lisboa, o narrador permite que o leitor detecte outras imprecisões do tempo. Note-se que essa personagem caminhou milhares de léguas e "Portugal inteiro esteve debaixo desses passos". Percebe-se que muito tempo gastaria Blimunda para caminhar milhares de léguas e no último capítulo, o narrador ilustra que ela havia passado mais de sete vezes, a pé, sem comer, por Lisboa e o tempo era chegado para ela. Tem-se, precisamente, a idéia de um tempo implícito ou imaginário, um temps chronique que, segundo Nunes, equivale ao tempo dos acontecimentos.

A respeito desse tempo imaginário aludido anteriormente, pode-se explicar que a obra literária, de caráter narrativo, de acordo com Nunes (1988, p. 26) insere-se em três possíveis planos: "o da história, do ponto de vista do conteúdo, o do discurso, do ponto de vista da forma de expressão, e o da narração, do ponto de vista do ato de narrar. O tempo da história, [o imaginário], depende (...) do tempo real". Do ponto de vista do conteúdo, Memorial do convento está centrada no relato de acontecimentos do século XVIII, o que interessa nesse trabalho.

Convém dizer ainda que no plano histórico e do ponto de vista da narração atual, o tempo pode ser caracterizado na ordem anacrônica em virtude de haver uma discrepância entre a ordem da história e a ordem que está sendo narrada. Gérard Genette (apud ERNST RUDIN) assevera que a anacronia é uma discordância entre el ordem de la historia y el ordem Del relato. Assim sendo, há que se ressaltar o fato de o romance Memorial do convento partir de uma retrospectiva histórica que da evocación de um acontecimento anterior al momento em que se encuentra el relato não quer dizer que se trata de uma analepse porque não há nenhuma referência de um relado anterior ao século XVIII. Entretanto, o ponto de partida da narração do Memorial do convento é, de fato, narrar uma história do século XVIII por meio de um processo conhecido por anamnesis (rememoração de acontecimentos), mas há a inserção da construção da basílica que supostamente estaria pronta no ano dois mil.

A volta ao passado, principiada pela memória, de certo modo, sustenta como artifício primordial o que se pode dizer superação dos tempos. Dir-se-ia que a obra é um encontro dos tempos e o leitor se vê na convivência entre passado e presente, tendo em vista que não há discrepância entre o antigo e o moderno no romance. 
Um fato que ajuda a explicar essa presentificação do tempo em Memorial do convento é o vôo da passarola do Padre Bartolomeu de Gusmão. Para essa leitura, considera-se uma obra imprescindível para compreender a narrativa de Memorial do convento. Trata-se, conforme citado no início deste artigo, de Carnaval no Convento: intertextualidade e paródia em José Saramago do crítico Odil Oliveira Filho. O autor observa que a partir do vôo em direção ao futuro, o texto de Saramago já supera o passado porque o leitor se depara com um passado transformado. A narrativa permite, ao leitor, uma visão de encontro dos tempos, em que passado e presente se fundem.

Notadamente, a obra aponta para o Portugal contemporâneo que alude à identidade do Portugal de dois séculos anteriores. Os momentos históricos são revistados pelo questionamento do caráter ideológico da História positivista, que ignora e silencia a verdade das relações humanas, omitindo fatos. A obra de Saramago contesta esses silêncios da História, contextualizando a ficção através de personagens históricos e ficcionais, bem como da fusão entre tempo e espaço. Percebe-se que o discurso ficcional se atualiza ao ser reconstruído no discurso literário.

A esse turno, Saramago realiza, em sua obra, um encontro dos tempos e da história, posto que os espaços em branco, deixados pelas versões da História, dão essa condição de reconstruir ficcionalmente os fatos implícitos, narrando, com primazia, o que poderia ter sido. Sob esse prisma, vê-se que a Ficção e a História entram em discrepância. Esse paradoxo, entretanto, direciona o leitor a uma determinada visão da História que, por sua vez, passa a ser questionada na obra. O romance permite que o destinatário faça indagações por intermédio da identificação e da internalização de outra visão histórica.

Paulatinamente às abordagens sobre o tempo na narrativa, o trabalho enfocará o foco narrativo. Para tratar do narrador de Memorial do convento pode-se, a princípio, aplicar a teoria da visão da narrativa de Jean Pouillon (1974) denominada visão com, visão de fora e visão de trás. No romance de Saramago há essas duas últimas visões. Tem-se a visão de fora em virtude da limitação do narrador, ao descrever acontecimentos, enfocando o exterior, sem adentrar no pensamento dos personagens. Note-se essa visão no capítulo onze, a seguir: 
Sentaram-se todos em redor da merenda, metendo a mão no cesto, à vez, se não outro resguardar de conveniências que não atropelar os dedos dos outros, agora o cepo que é a mão de Baltazar, cascosa como um tronco de oliveira, depois a mão eclesiástica e macia do padre Bartolomeu Lourenço, a mão exata de Scarlatti, enfim Blimunda, mão discreta e maltratada, com unhas sujas de quem veio da horta. (SARAMAGO, 1987, p. 227).

O narrador de Saramago possui todo um saber sobre a trajetória de vida e o destino final de todos os personagens. Trata-se de um foco narrativo capaz de direcionar as ações de seus actantes. Daí outra visão de Pouillon (visão de trás), como se verifica na sequiência:

Descansaram aqui e além no caminho, calados, nem tinham o que dizer, se até uma simples palavra sobra se é a vida que está mudando (...). Blimunda cata os bichos do cabelo de Baltazar, mas ele pouco pode ajudá-la: falta-lhe a mão. Não é verdade que a mão esquerda não faça falta. Um homem precisa das duas mãos, uma mão lava a outra...São onze os suplicados. A queima já vai adiantada, os rostos mal distinguem. Naquele extremo arde um homem a quem falta a mão esquerda. Então Blimunda disse, Vem. Desprendeu-se Baltazar Sete-Sóis (SARAMAGO, 1987, p. 302).

Ao analisar esses fragmentos pode-se asseverar que o narrador onisciente (editorial omnisciente), na tipologia de Norman Friedman, possui absoluta autonomia com a história narrada. Dir-se-ia que se trata de um narrador que sabe, vê, ouve e conta quase tudo a respeito do enredo. O narrador não transmite tudo sobre o destino de Baltazar e Blimunda, mas conduz o leitor passo a passo ao desenlace, o qual mantém o seu interesse pela nova história que está sendo contada. Vê-se que na metade da trama o foco narrativo explicita a falta da mão de Baltazar e a necessidade de Blimunda em ajudá-lo, uma vez que o narrador já se apropriava do provérbio popular "uma mão lava a outra". No desfecho, o narrador revela que Blimunda estenderia as suas mãos a Baltazar na tragédia ocasionada pelo incêndio, conforme consta nas citações anteriores.

A rigor, também interessa destacar que o narrador usa a terceira pessoa em junção com a primeira pessoa, transformando-se em cambiante, como está nitidamente demarcado nesse seguinte trecho: 
A ponto de há pouco tempo terem soltado uns cento e cinqüenta de culpas menos pesadas, que então estavam no Limoeiro, por junto, mais de quinhentos, com as muitas levas de homens que vieram para a Índia e (...) era tanto o ajuntamento, e a fome tanta, que se declarou uma doença que nos ia matando a todos, por isso soltaram aqueles, um deles sou eu... (SARAMAGO, 1987, p. 229).

Vê-se que a narrativa, ora apresenta um narrador heterodiegético e extradiegético que é o caso do narrador de fora, que narra a história do convento e a desconstrói a vida do reinado de D. João V: um narrador imparcial, ora um narrador intradiegético, quando Baltazar toma parte do discurso narrado, por exemplo, no instante em que o leitor lê, especificamente, esse trecho: "com as muitas levas de homens que vieram para a Índia e era tanto o ajuntamento, e se declarou uma doença que nos ia matando a todos, por isso soltaram aqueles, um deles sou eu".

Há ainda outro tipo de narrador designado, por Genette, de autodiegect em virtude de o narrador de Saramago permitir que os personagens (trabalhadores braçais) narrem suas histórias e assim refere-se a stary in which the narrator tells his own story. Esse nível de narrador pode ser encontrado a partir do capítulo dezoito, no instante em que o narrador, em terceira pessoa, distancia da história e, já ignorando a figura de D.João $\mathrm{V}$, transfere a voz aos personagens negados na historiografia portuguesa para contar sua própria narrativa.

É justamente esse narrador tido como "contador de histórias" que garante à narração um estilo que aproxima da oralidade, dialogando, por um lado, com o leitor. Por outro lado, a narrativa foge desse contato e não esconde objetivamente seu caráter de escrita, explicitando os procedimentos que o narrador, por meio do discurso romanesco, criou para ocupar o espaço vazio deixado pelos antigos ouvintes. Daí o fato surpreendente de Saramago, aos resgatar a arte de contar histórias que, na visão de benjaminiana, a partir do século XX, parece ter exaurido, uma vez que atualmente percebe-se que não há mais a capacidade de intercambiar experiências. Em $O$ narrador Benjamin (1980) afirma que a narrativa de modo algum não se exaure e o narrador que conserva a arte de contar histórias mantém-se vivo aos olhos do ouvinte, posto que:

Para o narrador (...), quanto mais se torna sua candidatura a um lugar na memória do ouvinte, tão mais plenamente as histórias se conformam à experiência pessoal dele, tanto maior é sua satisfação em voltar afinal a 
contá-la. Narrar histórias é sempre a arte de continuá-las contando e esta se perde quando as histórias já não são mais retidas. (BENJAMIN, 1980, p. 62).

Nesse sentido, pode-se elucidar que Saramago aproxima sua narrativa das tradições populares, mormente, ao permitir que seus narradores populares contem seus casos em várias passagens da narrativa. A rigor, a própria figura do narrador-contador de histórias dá possibilidade de visualizar esse tom popular como a arte de contar histórias.

No tocante aos narradores do Memorial do convento, pode-se dizer que durante a leitura passa a impressão no leitor de que há um narrador imparcial e distante da história narrada. Em certas passagens, fica difícil o seu desvelamento, pois o narrador parece ficar em pano de fundo. Entretanto, há momentos em que o narrador contador de histórias se vela, tornando-se explícito aos olhos do leitor que se configura como um observador. Veja-se, por exemplo, no caso do trecho, a saber:

Não é possível que Blimunda tenha pensado esta subtileza, e daí, quem sabe, nós não estamos dentro das pessoas, sabemos lá o que elas pensam, andamos é a espalhar os nossos próprios pensamentos pelas cabeças alheias e depois dizemos, Bimunda pensa, Baltazar pensou... (SARAMAGO, 1982, p. 340).

Ao ler o excerto acima, observa-se que, a partir do discurso indireto, a própria voz do narrador revela sua onipresença diante dos personagens. Não há como negar a presença de um possível contador de histórias nesse exemplo. Um narrador que critica a sua própria onisciência, afirmando que "andamos é a espalhar os (...) pensamentos e (...) dizemos, Blimunda pensou...”. É imprescindível observar a impressão de um narrador na história, o mesmo que discorre Benjamin, como já escrito antes. Há a marca do narrador que se constituiu como um artesão e, por assim dizer, expressa a cultura popular, pelo viés das marcas da narrativa oral que tem seu fulcro no contador de casos ou histórias.

Em várias passagens do discurso narrado, a figura desse contador pode ser encontrada, não só através de Baltazar ou dos trabalhadores de Mafra, mas ainda na voz do próprio Padre Bartolomeu de Gusmão, onde ele diz: “a quantos destes irá suceder entortar-se-lhes a história que tinham para entrarem nesta que vamos contando..." (SARAMAGO, 1982, p. 39). 


\section{Considerações finais}

À guisa de conclusão, pode-se asseverar que a obra se ocupa de um narrador que conversa com seus leitores, não como interlocução, usada por Machado de Assis, mas por intermédio de marcas menos diretas como se nota no trecho: "se achar que não tem o caso suprema dificuldade é porque não levou esta pedra de Pêro Pinheiro a Mafra e apenas assistiu a olhar de longe, do lugar e do tempo desta página" (SARAMAGO, 1982, p. 48). Indubitavelmente, evidencia-se que o narrador dialoga com o leitor no sentido de garantir a veracidade e confirmar a história sobre a transposição da pedra e da dificuldade dos trabalhadores na construção do convento de Mafra, não no tempo histórico, mas no tempo presente.

Memorial do convento permite uma variedade de leituras, seja pelo viés do discurso intertextual, seja pelos elementos da narrativa, entre outras possibilidades. Neste artigo, foi possível concentrar, à luz de teorias relativamente recentes acerca da narrativa, na problemática do tempo e do foco narrativo. Com esse artigo, abre-se a possibilidade de outras exegeses porque a análise literária se constitui sempre com uma continuidade, uma vez que segundo Maurice Blanchot (1987, p. 24), “escrever é descobrir o interminável”, e o fascínio da escrita se insere na perspectiva do olhar sobre o eterno recomeço. É nesse sentido que o leitor termina uma leitura de Memorial do convento, sempre com a necessidade de recomeçar, de prender-se nos satélites da Ficção e da História, na decifração e recifração do encontro dos tempos, do antes e do agora, por meio do discurso dialógico.

\section{REFERÊNCIAS}

BENJAMIN, Walter. "O narrador”. In: . Textos escolhidos. São Paulo: Abril Cultural, 1983 (Os pensadores).

. "Sobre o conceito de História". In: Magia e técnica, arte e política: ensaios sobre literatura e história da cultura. 2. ed. Trad. Sérgio Paulo Rouanet. São Paulo: Brasiliense, 1986. 


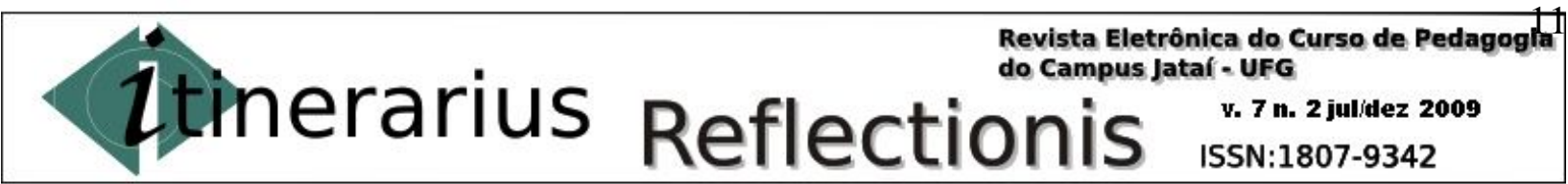

BAKHTIN, Mikhail. Questões de literatura e estética. A teoria do romance. São Paulo: UNESP/HUCITEC, 1988.

1970.

. De François Rabelais et la culture populaire. Trad. André Robel, Paris: Gallimard,

BARROS, Diana.Luz.Pessoa.(org). Dialogimo, polifonia, intertextualidade: em torno de Bakhtin. São Paulo: Edusp, 1994 (Ensaios de Cultura, 7).

BLANCHOT, Maurice. O espaço literário. Trad. Álvaro Cabral. Rio de Janeiro: Rocco, 1987.

FILHO, Odil Oliveira. Carnaval no Convento: intertextualidade e paródia em José Saramago. São Paulo: EDUNESP, 1993.

GENETTE, Gerard. Discurso da narrativa. Lisboa. Vego/ Universidade. s/d.

GODOY, Heleno. "Uma Antologia para alunos da disciplina TN-14: Teoria da Narrativa". Vol I. Goiânia: UFG, 2007. In: TALIB, Ismail S. Narrative Theories. Disponível em http:// courses.nus.edu.sg/couse/ellibst.

MARTINS, Adriana Alves de Paula. "Memorial do Convento ou a Superação do(s) Abuso(s) da Memória". In: Revista Agulha. IV Congresso Internacional da Associação Portuguesa de Literatura Comparada. Vol 5.Lisboa: Universidade Católica Portuguesa (Viceu), 1994, p. 1-12.

NUNES, Benedito. O tempo na narrativa. São Paulo: Ática, 1988.

POUILLON, Jean. O tempo no romance. São Paulo: Cultrix/Edusp, 1974.

RICOUER, Paul. Tempo e narrativa. Trad. Constança Marcondes Cesar (Tomo I), Marina Appenzeller (Tomo II) e Roberto Leal Ferreira (Tomo III). Campinas, SP: Papirus, 1994, 1995, 1997.

. Introduction. In: Le temps et les philosophies. Paris, Payot/Unesco, 1978, p. 16

RUDIN, Ernest. Introdução a la terminologia de Genette. Disponível em http:// www.elneto.com/hista/ZH2003/index.html. Acesso: 19.03.07 por Heleno Godoy.

SACKS, Sheldon. Ficcion and Shape of Belief. Trad. Heleno Godoy. (Chicago: University of Chicago press, 1964.

SARAMAGO, José. Memorial do convento. 4. ed. Rio de Janeiro: Bertrand do Brasil, 1987. 